\title{
Evidence Beyond the Rules: A Critical Thinking Approach to Teaching Evidence Law to Undergraduate Students
}

\author{
Stephen R. Arnott \\ Hamline University \\ sarnott01@hamline.edu
}

\begin{abstract}
This article suggests that using a critical thinking approach in teaching undergraduate courses such as Evidence is not only consistent with education in the liberal arts but offers valuable opportunities to enhance student learning, develop transferable skills, and explore interdisciplinary connections.
\end{abstract}

Keywords: evidence, rules, critical thinking, transferable skills, pedagogy, interdisciplinary.

There is an old story about a criminal defense attorney who was defending a homicide case where there was no body. During closing arguments, the lawyer gestured towards the courtroom door and said that the jury had to find the defendant not guilty because the allegedly dead person would walk in within 30 seconds. No one walked in but the lawyer said that merely proved his point because every juror had looked at the door and waited. That they had done so meant that there was reasonable doubt and that they must acquit the defendant. The jury retired and quickly returned with a guilty verdict. The lawyer was incredulous and later asked the foreman, "How could you find the defendant guilty? You all looked at the door!" "Yes, we did," replied the foreman, "but your client didn't."

What a lawyer says in a trial is, of course, not evidence but lawyers craft their words to persuade a jury (or the judge in a bench trial) of what the facts are. In the story, the judge did not instruct the jury as to the law; nor is there any obvious reference to the rules of evidence. Rather, the jury critically thought about what the lawyer argued and reasoned its way to a more likely explanation of what happened.

While amusing enough in itself, the story illustrates why I have rethought the way in which we might teach evidence, and indeed other courses, in ways that encourage students to think critically about the rules and the nature of evidence itself. This in turn involves approaching the law of evidence as contributing significantly to ". . . the overarching goals of a university education, by inculcating relevant, robust and adaptable (more or less) transferable skills, [and] helping students to become lifelong learners ..." (Roberts 2002, p. 301), particularly given that there is widespread modern acceptance that colleges should produce broad, transferrable skills (Berrett, 2016.). This is not to say that an evidence course should be completely theoretical and devoid of assignments that introduce or reinforce practical skills. Rather, I emphasize the "why" behind evidentiary rules as necessary to understand the "how" of their practical application. I begin this article by explaining the background to the critical thinking approach that I advocate as both desirable and appropriate for teaching evidence to undergraduate and paralegal students. I then illustrate some of the ways one can integrate broader critical thinking skills into an undergraduate evidence course and explore the interdisciplinary and intradisciplinary opportunities that I believe flow from, and can be used to, enrich the students' experience. Finally, I suggest that, while some questions remain to be answered by further research into student performance, a critical thinking approach, combined with practical assignments, is likely to be both pedagogically sound, to best 
prepare students for both the academic and professional aspects of the law, and to contribute significantly to broader student success by developing transferrable skills that cross disciplinary boundaries.

\section{Background}

When I started teaching Evidence (or, to give the course its full name, the Law of Evidence for Legal Professionals) I inherited a course and a syllabus and it made sense to teach according to what I had inherited. The course focused on the Federal Rules of Evidence - though, where appropriate, I drew students' attention (and still do) to differences between the Federal rules and the Minnesota rules - starting with Rule 101 and proceeding inexorably through the rules on hearsay. However, like others (Shapiro, 1996), I have also come to think that not covering hearsay earlier in the course also may be a mistake because it is the one rule that students usually think they understand and are dismayed, much later in the course, to find that usually they do not. Moreover, some sequencing did not make complete sense. For example, the rules on authentication, documentary evidence and privileges were treated later and separately - not precisely as afterthoughts - but in a way that did not seem to be part of an intelligible whole. But I had not taught evidence before and I thought it made sense not to try to reinvent the wheel. Inertia being what it is, I continued to teach evidence in much the same way each year. Although I did change some aspects of the course, they were largely stylistic changes and focused on course delivery rather than course substance. Looking back now, this probably foreshadowed the direction I am now taking. In the meantime, however, I rather prided myself on the fact that I was teaching a rigorous course in a rigorous way; that I was challenging to students to think like legal professionals; and that I was helping them to become thoroughly familiar with the rules.

However, I now believe that my initial approach was mistaken and that I was treating the undergraduate evidence course as "law school lite." This meant focusing very closely on the Federal Rules of Evidence to the exclusion of a more rounded, theoretical, and holistic understanding of why we have evidentiary rules in the first place and of how they operate. In fact, the law of evidence is one of the most interesting and, sometimes, the most vexing courses that an undergraduate student might take; one that is ". . . bedevilled by technical complexity and conceptual difficulties" (Twining, 1990, p. 208) or, as James Bradley Thayer (1898) described it many years ago, one that is ". . . a piece of illogical, but by no means irrational patchwork; not at all to be admired, nor easily to be found intelligible, except as a product of the jury system . .." (p. 509). Admittedly, Thayer was writing well before the rules of evidence were codified but codification has not necessarily replaced complexity with simplicity. More recently, the United States Supreme Court confirmed Thayer's thinking by noting that “. . . our rules of evidence ... . have their source very often in considerations of administrative convenience, of practical expediency, and not in rules of logic" (Shepard v. United States, 290 U.S. 96, 104 (1933)). Whether convenience and expediency are proper bases for evidentiary rules is beyond the scope of this article but at least one commentator has argued that they are not (Klein, 2013).

Consequently, it is difficult to explain (and understand) evidentiary rules, if one does not understand what evidence actually is and what it is for. For example, if a court excludes some fact from a jury's consideration, then that fact is not "evidence." Or, to put it another way, it does not cease to be evidence; it becomes inadmissible evidence either because it is irrelevant or for another reason (Fed. R. Evid. 402). Because the Rules are largely a series of exceptions to admissibility, we spend much time considering why a fact is not actually going to be evidence.

Journal of the Scholarship of Teaching and Learning, Vol. 18, No. 4, December 2018. josotl.indiana.edu 
That is not to say that it is unimportant to think about why we might want to exclude particular facts or types of facts. But it seems to me that exclusionary rules will probably make more sense (or at least be more understandable) when we better understand related concepts. For example, the science of probability and the nature of facts and proof can be integrated into broader questions about why we think of something as being evidence in the first place. To do so is to recognize, as Thayer pointed out, that ". . . we must discriminate between different senses of the word "evidence"" (Thayer, 1898, p. 391). Modernly, no less than for Thayer well before the rules of evidence were codified, what we think of as the "law of evidence" essentially means the rules that do not, themselves, “. . . determine questions of mere logic or general experience, or furnish rules of conducting processes of reasoning" (Thayer, 1898, p. 391). However, when we supplement rule-based learning with logic, general experience, and reasoning processes, we provide important context, without which ". . . the law of evidence can seem like a disparate rag-bag of rules with little in common” (Palmer, 2011, p. 564).

Moreover, undergraduate Evidence courses are ideal places to introduce the theoretical bases of the law of evidence for at least two reasons.

First, facilitating critical thinking in an undergraduate Evidence course fosters success in tasks that are central to liberal, disciplinary, and professional education particularly if the supposed trade-off between teaching content and facilitating critical thinking skills is actually illusory (Nelson, 1999). While some have argued that "critical thinking" is actually a nebulous concept (Schaberg, 2015), to the extent that "critical thinking" does have content, and I think it does, using it gives us an important opportunity to focus on skills that cross disciplinary boundaries and are fundamental to the liberal arts. Critical thinking skills require ". . . grounding one's beliefs in evidence rather than emotion or desire, and learning how to search for and evaluate evidence that might contradict one's initial hypothesis" (Lukianoff \& Haidt, 2015). By focusing on fundamental questions underlying the law of evidence, we can help students develop such skills within our field - the law - and to ask questions about, and understand, the "why" instead of just absorbing the "what." Students are then better able to understand the complexities beneath the surface (Nosich, 2009). For example, drawing on feminist legal scholarship, a teacher might use (and I do) hypothetical problems that can encourage students to engage with issues of feminist concern by probing their own biases and assumptions (Kinports, 1991; Orenstein, 1999). Such hypothetical problems also provide an opportunity for students to think about evidentiary rules from different points of view and recognize that "the context in which rules are applied deeply affects their meaning" (Aiken, 2006, p.1076). They also allow students to explore the ways in which multiple evidentiary rules might come into play and learn how important it is to think critically about problems and probe beneath their surface.

Second, undergraduate courses enable us to tie together interdisciplinary components of, for instance, law, philosophy, criminal justice, and history, consistent with the proposition that "[t]eaching and learning in a university setting should ideally be a collegial enterprise of intellectual discovery and personal development, which properly embraces instrumental goals, but is not reducible to them" (Roberts, 2002, p. 300). This includes exploring shared conceptual terrains of leading ideas, including, for example, the close connections between logic and law in embracing ideas such as evidence, probability, relevance, reasonableness, precedent, presumption, plausibility, explanation, and proof (Gabbay \& Woods, 2010). But a critical thinking-focused approach goes much further than just exploring ideas, important though that is, and enables us to connect very clearly a theoretical understanding of evidence with practical policy-making. For example, in their 2012 book critiquing dominant policy making methods and focusing on strategies

Journal of the Scholarship of Teaching and Learning, Vol. 18, No. 4, December 2018. josotl.indiana.edu 
for success, Nancy Cartwright and Jeremy Hardie build their recommendations on a theory of relevance and, in examining where public policy-making has failed where it might have been expected to succeed, they make it clear that their approach ". . . is not just bluff and practical - the plain man's way of cutting through the complexity of statistical evidence, probability theory, and so on to hard, coal-face facts that will lead to realistic predictions" (p. 14). Rather, they focus on a theory of relevance that can be used to support facts bearing on policy predictions and which can be useful for policy implementation - that is to say, one that is built on sound argumentation. (pp. 18-22). Similarly, though in a different context, others have recently highlighted the need for sound empirical reasoning and trenchantly argued for renewed emphasis not only on evidence-based medical and scientific research (which one might think would go without saying, but does not) but also on evidence-based activism and ethics (Dreger, 2015.) In other words, returning to the story that opened this article, the way in which a jury might operate by reasoning from known facts (the defendant didn't look at the door when one would have expected him to) to a conclusion (the defendant did it).

Additionally, the practical value of a critical-thinking approach goes beyond policy-level analysis and, of course, beyond just Evidence as a course, to the no less important consideration of preparing students for work. In a law-related environment, this could be working as paralegal where, according to the American Association for Paralegal Education, success requires that an individual should possess not only a common core of legal knowledge, but must also have acquired vital critical thinking skills (AAfPE, 2013). But critical thinking skills are equally important in preparing students to perform other degree-required jobs. To take a non-legal example, a graduate candidate for a "working apprenticeship" for medical device marketing managers and salespeople was not hired, despite having a degree in scientific and technical communication, because the student's curriculum failed to enable him to develop the ability to learn and communicate any subject even remotely as scientific or technical as a medical device (Root, 2014). However, this was not a call for a curriculum that emphasized "hard science" so much as an argument for returning to the traditions of a liberal arts education with substantive courses that required students to "learn how to learn" (p. D6). It is, of course, possible that the candidate in this example had taken courses that emphasized thinking and reasoning skills but that he had simply not internalized those skills or learned how to use them. It is also possible and, some would argue, likely that colleges do not know how to produce the skills - like problem solving and analytical thinking that employers expect recent graduates to possess and that, while students may feel qualified in areas like written and oral communication, critical and analytical thinking, applying knowledge and skills to the real world, employers consistently rate students lower than they rated themselves (Fabris, 2015). Either way, though, this example means for me that we should both teach courses that address such skills and that we should teach them effectively. Moreover, we can do so in courses rich in discipline-specific content or in courses that draw on everyday life events to develop critical thinking skills (Facione, 1990). An Evidence course naturally contains much discipline-specific content but it also offers opportunities to move students' cognitive activity from attending mainly to formal rule systems to becoming able to attend to context (Sullivan, 2007). In doing so, they are developing both disciplinary-specific and broader thinking and analytical skills that cross disciplinary boundaries and which are useful in broader contexts. Thus, it is no coincidence that courses specifically emphasizing evidence-based reasoning have begun to attract greater attention (Berrett, 2016).

Additionally, research previously undertaken into college graduates' critical thinking skills reinforces how important faculty, employers, and policymakers think these skills are (Jones et al.,

Journal of the Scholarship of Teaching and Learning, Vol. 18, No. 4, December 2018. josotl.indiana.edu 
1995). In determining whether consensus could be reached about the important writing, speech and listening, and critical thinking skills that college graduates should achieve to become effective employees in the workplace and citizens in society, researchers viewed critical thinking as a generic skill that is both interdisciplinary and encompasses diverse employment responsibilities (pp. 3-4). Significantly, while study participants differed on how important they viewed specific skill-sets, they did agree on many important critical thinking skills that college graduates should achieve (p. 164). In particular, they agreed on the importance of inference skills involved in collecting and questioning evidence and the extent to which college graduates were able to judge if there was sufficient evidence to support a conclusion (pp. 142-43). Perhaps unsurprisingly, employers providing legal services stressed the importance of strong logical reasoning skills for working in departments that have legal implications (p. 141). For these reasons, an effective Evidence course should emphasize critical thinking skills with practical assignments applying legal knowledge that replicate the type of work that a paralegal might expect to do for a lawyer supervisor.

In suggesting the merits of teaching evidence law from a critical thinking perspective, I recognize that such an approach in general is not new and that authors have stressed how useful it is in introductory materials designed for prelaw and paralegal students and for students who are less directly interested in the law (Currier \& Eimermann, 2009). It is certainly true that this approach is valuable in that it avoids having students merely memorize definitions and rules and instead "... focuses on the basic foundations of the law and of the legal reasoning process" (p. xl). Learning foundational skills including reading, analyzing, and applying statutes, cases, and other legal materials is unquestionably important and it is appropriate to focus on these skills in texts designed specifically for legal research and writing courses (Putman \& Albright, 2014). Pedagogical techniques that encourage students to ". . . think about and discuss the underlying assumptions behind various aspects of the law and the ramifications of different approaches to legal problems" (Currier \& Eimermann, 2009) are also similarly valuable. Taken together, the pedagogical techniques embodied in the critical thinking approach are also specifically appropriate to preparing students for later Evidence courses in law school where students must apply evidentiary rules in more or less complex hypothetical situations. It is unsurprising, therefore, that Evidence treatises directed towards law students explore the theoretical basis of evidentiary rules regarding, for example, expert witness testimony and hearsay in some detail (Mueller \& Kirkpatrick, 2012). Thus, a student exposed, either as an undergraduate or as a post baccalaureate new to the law, to rigorous analysis of such theoretical bases for evidence rules has both an absolute good (critical thinking skills) and a comparative advantage (over others who are not similarly prepared).

\section{Integrating critical thinking skills into an undergraduate evidence course and exploring interdisciplinary and intradisciplinary opportunities}

\section{Developing Critical Thinking Skills In Evidence Courses}

In Evidence, like other legal studies courses, students can be encouraged to think critically by having them apply legal rules to different hypothetical situations. Typically, one of the measures we use to assess students is how well they are able to apply rules to facts. In addition to extensively using this legal education staple, however, I have flipped the concept by having students develop their own questions and hypothetical situations as a way of getting them to think about the rules.

Journal of the Scholarship of Teaching and Learning, Vol. 18, No. 4, December 2018. josotl.indiana.edu 
This technique has proved useful in provoking large and small group discussion, as has having students be responsible for explaining a particular rule to other students.

Additionally, one of the advantages of teaching a rule-based course is that the materials readily lend themselves to using charts and similar devices to explain how the elements of various rules and, indeed, the different rules fit together. For example, one might devise a flow chart of the rules that apply to character evidence, rather like the very useful chart that Professor George Fisher (2002) developed (p. 140). The character evidence chart simplifies the rules by illustrating the steps and links between them and by enabling students to visualize a process. Consistent with a critical thinking approach, however, I have tried to take this further by having students construct their own individual charts based on how they understand the rules and then, in groups, identifying ways in which they could clarify and improve the charts before comparing them with an instructorsupplied chart.

Another example of visually representing evidentiary rules and their rationales is Professor Laurence Tribe's (1974) famous evidence triangle (p. 957). Professor Tribe's triangle is designed to diagram the dangers of ambiguity, insincerity, erroneous memory, and inaccurate perception that have been traditionally associated with hearsay evidence (Mueller \& Kirkpatrick, 2012). Using diagrams such as this one can supplement written and oral explanations and can benefit students by providing an alternative medium for them to process information and understand the rules.

A further method is to use multimedia resources to enhance student understanding. It is, of course, not unusual to use movie clips for pedagogical purposes and this is certainly true in an Evidence course where they can be useful to illustrate evidentiary principles or provide context for students to better understand how evidentiary rules operate. The context is important because often "[t]eaching Evidence to students who lack understanding of the trial process [for example] is like teaching "the crawl" to someone who has no idea what a swimming pool or other body of water looks like" (Bergman, 2001, p. 974). Traditionally, multimedia resources meant movie clips and I use them in my own course where Charles Laughton and Joe Pesci bring witness impeachment vividly to life in very different contexts in Witness for the Prosecution and My Cousin Vinny respectively. Movies can also offer expanded opportunities for students to think critically about evidentiary issues. Now, of course, we are able to use many additional and different resources. For example, in a recent course I used "Serial," a recent series of podcasts that had drawn widespread interest and commentary among lawyers and the public. Interestingly, however, the overwhelming majority of students in the class had neither listened to, nor knew about, the program, which focused on the 1999 investigation, trial, and conviction of a Baltimore high school student for murdering his former girlfriend (Koenig, 2015). While the podcasts did not specifically deal with evidentiary rules, they were augmented by a very useful series of separately authored blog posts on evidentiary issues that the podcasts raised (Miller, 2015). I divided the class into three "juries" with the objective being not replicate an actual jury experience so much as to give students the opportunity to think critically about evidence and advance and analyze their own and other perspectives. I then created Blackboard discussion groups for each jury. While I did not prohibit students from listening to episodes ahead of the one scheduled for a particular week, I told them that they did not need to and that there would be no advantage in doing so. In fact, the comments in the discussion boards suggested that they had not. After listening to each podcast, which I made available as a weekly link in Blackboard, students posted comments on the case and the evidentiary issues they identified. We were then able to devote subsequent class time to aspects of the case that students had already thought about and discussed which, in turn, resulted in a richer exchange

Journal of the Scholarship of Teaching and Learning, Vol. 18, No. 4, December 2018. josotl.indiana.edu 
of ideas. The level of student participation in the discussion boards was not uniform, of course. However, it was enhanced by the fact that I used a discussion rubric and scored their contributions. Students evaluated this teaching technique positively after the course and it is one that I am repeating in a current course. However, rather than using "Serial" again, I am using the movie 12 Angry Men as the springboard for discussion. The class is divided into three juries and, after watching the movie, jurors vote individually via Blackboard whether to convict or acquit followed by an opportunity to discuss their reasons for doing so. We then move to evidentiary issues the movie raises and it is here that students can begin to think about evidentiary issues in ways that force them to question assumptions, think critically about how the jury in the movie actually reasoned about facts and assessed the evidence, and confront the possibility that the jury in the movie actually got it wrong by acquitting a guilty man because they did not assess for plausibility the alternative innocence narratives that they had concocted (Vidmar et. al, 1997).

\section{Interdisciplinary Opportunities Arising from a Critical Thinking Approach}

In addition to specific issues that naturally arise in a legal studies course, a critical thinking approach towards teaching Evidence creates significant interdisciplinary opportunities that benefit students.

One exercise that I have introduced into my Evidence course has been to enlist colleagues outside my own department in helping students consider what "evidence" means. This has involved posing a seemingly straightforward question such as "What is evidence?" and having professors in other disciplines including history, physics, chemistry, and religion visit my class and discuss how they would answer that question. Similarly, one can pose a famous (or infamous) question about facts and evidence such as whether absence of evidence is evidence of absence (where puzzled looks usually give way to enthusiastic discussion) and look at it from a philosophical approach. Indeed, as already noted, the close relationship between concepts such as logic and probability with evidentiary questions such as relevance offer opportunities to consider symbolic logic and statistical probability as alternative ways for students to think about relevance, for example (Gabbay \& Woods, 2010).

Of course, the natural constraints resulting from the ground that one must cover in an Evidence course limits the time that might be devoted to exploring evidentiary concepts from an interdisciplinary perspective. However, my colleagues have enthusiastically embraced the idea and students have responded positively to the opportunity of thinking about how a historian might approach evidentiary sources; how we might think about evidence and faith in a religious context; and what evidence means for natural scientists. Additionally, in future courses I can include other disciplines such as psychology, anthropology, political science, and mathematics and explore comparisons and contrasts that arise. There are going to be overlaps between disciplines and making those connections is just as important for students as exposing them to the differences between disciplines and encouraging them to think about those differences. Moreover, there are disciplines that one might not intuitively think of, such as music, art, or theater, but where thinking about evidence and facts crosses disciplinary boundaries as faculty members define what evidence means in their own disciplines. This includes, for example, evidence-based courses in art history (Berrett (2016). 


\section{Intradisciplinary Opportunities Arising from a Critical Thinking Approach}

Teaching Evidence, or any other legal studies course for that matter, from a critical thinking perspective also enables one to explore connections within legal studies in at least two ways.

First, there are clear connections between legal concepts and evidentiary rules in the sense that evidentiary issues arise in the context of real cases, either civil or criminal, and involve real legal issues of liability or guilt. But one can draw on other courses such as Legal Interviewing, which I also teach, to help students think about why lawyers and paralegals care about witnesses and facts and how investigation and interviewing relates to how evidentiary rules function in practice, rather than teaching courses such as these in isolation and, in the case of Evidence, just focusing on the text of the rules.

Second, because students have been thinking about the theoretical bases of evidentiary rules, they have greater context when I introduce legal professionals - judges, lawyers, and paralegals - to augment different parts of the course by attending as guest speakers. Having that context can be somewhat disconcerting when students realize that trial judges often can, and must, decide evidentiary issues and rule on objections very quickly. But having some grasp of the basis for a particular rule can make it much easier for students to understand the legal arguments for excluding evidence in a motion in limine that a paralegal is drafting for the supervising attorney or the thinking behind a judge's evidentiary ruling. Consequently, students are better prepared for either law school or working in a law-related environment.

\section{Conclusion}

Teaching any college course from a critical thinking perspective is neither a radical nor a necessarily novel approach. Moreover, embedding critical thinking in courses makes more sense than trying to teach critical thinking itself. In this article, I have highlighted the values that seem to me to be advanced by adopting a critical thinking approach to teaching Evidence. To some extent, however, the jury is still out on how students do benefit both within an Evidence course and across other courses and I have begun that assessment work. Nevertheless, I believe strongly that teaching Evidence using a critical thinking perspective, combined with practical assignments achieves multiple pedagogical objectives: it helps students develop skills that are integral to learning the law and practicing in a law-related profession; exposes students to ways of thinking about evidentiary issues derived from other disciplines; develops transferrable skills that are consistent with a liberal arts education; and it enhances student understanding of evidentiary rules by putting those rules in context - a context that emphasizes that evidence is something that goes beyond the rules.

\section{Acknowledgments}

I am indebted to one of my Mathematics department colleagues, Prof. Art Guetter, for the story at the beginning of this article. Professor Guetter frankly admits that he might have heard it from someone else.

\section{References}

Aiken, J. H. (2006). Teaching the rules of "truth." Saint Louis University Law Journal, 50(4), 1075-1090. Retrieved from https://scholarship.law.georgetown.edu/facpub/1640/.

Journal of the Scholarship of Teaching and Learning, Vol. 18, No. 4, December 2018. josotl.indiana.edu 
Arnott

American Association for Paralegal Education (2013). AAfPE core competencies for paralegal programs. Retrieved from http://online.fliphtml5.com/uuro/ysbc/\#p=2.

Bergman, P. Teaching evidence the "reel" way. Quinnipiac Law Review, 21(4), 973-992. Retrieved from https://heinonline.org.

Berrett, Dan (2016, April 3). If Skills Are the New Canon, Are Colleges Teaching Them? The Chronicle of Higher Education. Retrieved from https://chronicle.com/article/If-SkillsAre-the-New- Canon/235948?cid=at\&utm source=at\&utm medium=en\&elqTrackId $=\mathrm{d} 8 \mathrm{f0cd0a} 249 \mathrm{c} 491 \mathrm{~b} 8 \mathrm{c} 977538 \mathrm{ae} 39728 \mathrm{a} \& \mathrm{elq}=34 \mathrm{bc} 9 \mathrm{dacbc} 8 \mathrm{a} 4916884 \mathrm{f5621e76162 \textrm {a } 4 \&}$ elqaid $=8525$ \&elqat $=1 \&$ elqCampaignId $=2819$

Cartwright, N., \& Hardie, J. (2012). Evidence-based policy: A practical guide to doing it better. New York, NY: Oxford.

Currier, K. A., \& Eimerman, T. E. (2009). Introduction to law for paralegals: A critical thinking approach (4th Ed.). New York, NY: Aspen.

Dreger, A. (2015). Galileo's middle finger: heretics, activists, and the search for justice in science. New York: Penguin Press.

Facione, P. A. (1990). Critical thinking: A statement of expert consensus for purposes of educational assessment and instruction. Newark, DE: American Philosophical Association. Retrieved from https://eric.ed.gov/?q=Facione\&ff1=autFacione $\% 2 c+$ Peter + A.\&id=ED315423.

Fabris, C. (2015, January 20). College students think they're ready for the work force. Employers aren't so sure. The Chronicle of Higher Education. Retrieved from https://chronicle.com/article/College-Students-Think/151289

Fisher, G. (2003, Spring). Compelling evidence [Interview by J. Rabinovitz]. Stanford Lawyer, $37(2), 8-12$.

Fisher, G. (2002). Evidence. New York, NY: Foundation Press.

Fonda, H. (Producer), Rose, R. (Producer), \& Lumet, S. (Director). (1957). 12 angry men [Motion picture]. United States: Metro-Goldwyn-Mayer.

Friedman, R. L. (2004). The elements of evidence (3rd. ed.). Saint Paul, MN: West Academic.

Gabbay, D. M., \& Woods, J. (2010). Logic and the law: Crossing the lines of discipline. In D. M. Gabbay, P. Canivez, S. Rahman, \& A. Thiercelin (Eds.), Approaches to legal rationality (pp. 165-201). New York, NY: Springer.

Jones, E. A., Hoffman, S., Moore, L. M. Ratcliff, S., Tibbetts, B., \& Click, A. L. (1995). National assessment of college student learning: Identifying college graduates' essential skills in writing, speech and listening, and critical thinking. Washington, DC: U.S. Department of Education National Center for Education Statistics. Retrieved from https://eric.ed.gov/?id=ED383255.

Kinports, K. (1991). Evidence engendered. University of Illinois Law Review, 1991(2), 452-55. Retrieved from https://elibrary.law.psu.edu/fac works/185/.

Klein, K. S. (2013). Why federal rule of evidence 403 in unconstitutional and why that matters. University of Richmond Law Review, 47(4), 1077. Retrieved from https://scholarlycommons.law.cwsl.edu/fs/61/.

Koenig, S. (Producer). Serial [Audio podcast]. Retrieved from https://www.serialpodcast.org.

Launer, D. (Producer), Schiff, P. (Producer), \& Lynn, J. (Director). (1992). My cousin Vinny [Motion picture]. United States: Twentieth Century-Fox.

Lukianoff, G., \& Haidt, J. (2015, September). The coddling of the American mind. Atlantic Monthly, 316(2), 42-52.

Journal of the Scholarship of Teaching and Learning, Vol. 18, No. 4, December 2018.

josotl.indiana.edu 
Miller, C. EvidenceProf [Web log]. Retrieved from https://lawprofessors.typepad.com/evidenceprof.

Mueller, C. B., \& Kirkpatrick, L.C. (2012). Evidence (5th ed.). Saint Paul, MN: Thomson West.

Nelson, C. E. (1999). On the persistence of unicorns: The trade-off between content and critical thinking revisited. In B.A. Pescosolido \& R. Aminzade (Eds.), The social worlds of higher education: Handbook for teaching in a new century (168-184). Thousand Oaks, CA: Pine Forge.

Nosich, G. M. (2009). Learning to think things through: A guide to critical thinking across the curriculum (3rd Ed.). Upper Saddle River, NJ: Pearson Prentice Hall.

Orenstein, A. (1999). Feminism and evidence. In B. Taylor, S. Rush, \& R. J. Munro (Eds.), Feminist jurisprudence, women and the law: critical essays, research agenda, and bibliography (pp. 507-538). Littleton, CO: F.B. Rothman.

Palmer, A. (2011). Why and how to teach proof. Sydney Law Review, 33(3), 563-573. Retrieved from www.austlii.edu.au/au/journals/SydLawRw/2011/24.pdf.

Putnam, W.H., \& Albright, J. R. (2014). Legal research, analysis, and writing (3rd ed.). Clifton Park, NY: Delmar Cengage Learning.

Roberts, P. (2002). Rethinking the law of evidence: A twenty-first century agenda for teaching and research. Current Legal Problems, 55(1), 297-345. Retrieved from https://doi.org/10.1093/clp/55.1.297.

Root, H. (2014, April 21). No hard sciences? Then no job offer. Minneapolis Star Tribune, p. D6.Schaberg, C. (2015, June 11). Thinking critically about critical thinking [Web log post]. Retrieved from https://www.publicbooks.org/thinking-critically-about-critical-thinking/

Shapiro, S. J. (1996). The use and effectiveness of various learning materials in an evidence class. Journal of Legal Education, 46(1), 101-109.

Shepard v. United States, $290 \quad$ U.S. $96 \quad$ (1933). Retrieved from https://supreme.justia.com/cases/federal/us/290/96/.

Sullivan, W.M., Colby, A., Wegner, J. W., Bond, L., \& Shulman, L.S. (2007). Educating lawyers: Preparing for the profession of law. San Francisco, CA: Jossey-Bass/Wiley.

Thayer, J. B. (1898). A preliminary treatise on the law of evidences at the common law. Boston, MA: Little, Brown.

Tribe, L. (1974). Triangulating hearsay. Harvard Law Review, 87(5), 957-974. Retrieved from http://dx.doi.org/10.2307/1340046.

Twining, W. (2006). Rethinking evidence: Exploratory essays (2nd ed.). New York, NY: Cambridge.

Vidmar, N., Beale, S.S., Chermerinsky, E., \& Coleman, J. E. (2007). Was he guilty as charged? An alternative narrative based on the circumstantial evidence from "12 Angry Men." Retrieved from https://scholarship.law.duke.edu/faculty_scholarship/1814/. 